\title{
LETTER
}

\section{Unexpected hemophagocytic syndrome in a post-cardiac surgery patient}

\author{
Lisa Linthorst*1 ${ }^{*}$ Heleen Aardema ${ }^{2}$ and Jaap E Tulleken ${ }^{2}$ \\ See related research by Beutel et al., http://ccforum.com/content/15/2/R80
}

In a recent issue of Critical Care, we read with interest the article on the incidence of hemophagocytic lymphohistiocytosis (HLH) in patients with H1N1 infection [1]. Acquired HLH is associated with infections (particularly viral), malignancy, and auto-immune disorders [2].

We describe a case of HLH in a 66-year-old woman admitted to the intensive care unit after aortic valve replacement. She had a history of a cerebral vascular event and diabetes mellitus type 2 . After surgery, she had an unexplained increase in oxygen demand and a fever. Standard antibiotics were started for probable ventilatorassociated pneumonia and were discontinued after negative cultures. A cardiac evaluation showed good valve patency.

Laboratory tests showed elevated creatine kinase $(3,562 \mathrm{U} / \mathrm{L})$, lactate dehydrogenase $(1,380 \mathrm{U} / \mathrm{L})$, ferritin $(3,960 \mu \mathrm{g} / \mathrm{L})$, and triglyceride $(2.29 \mathrm{mmol} / \mathrm{L})$ and decreased hemoglobin $(64 \mathrm{~g} / \mathrm{L})$, platelets $\left(54 \times 10^{9} / \mathrm{L}\right)$, fibrinogen $(1.0 \mathrm{~g} / \mathrm{L})$, and haptoglobin $(<0.2 \mathrm{~g} / \mathrm{L})$. The results of a Coombs test were negative. Schistocytes were absent. Bone marrow aspiration showed marked hemophagocytosis. An eliciting factor could not be found. Because criteria for HLH were met, we started prednisone treatment. Our patient made a satisfactory recovery.

Fever, thrombocytopenia, and anemia are common after cardiac surgery. Without the finding of a markedly elevated ferritin level in our patient, the proper diagnosis could have been missed or her condition could have been misclassified as sepsis with multiple organ failure [3]. To the best of our knowledge, this is the first published case of HLH to occur after cardiac surgery but without a known eliciting cause. This raises a tantalizing thought: unknown triggers may have a role in the pathogenesis of HLH. It would be interesting to search for HLH in a cohort of cardiac surgery patients.

Abbreviation

HLH, hemophagocytic lymphohistiocytosis.

\section{Competing interests}

The authors declare that they have no competing interests.

\section{Acknowledgments}

Our patient provided written consent to the publication of this letter.

\section{Author details}

'Department of Critical Care and Anesthesiology, Antonius Hospital Sneek, Bolswarderbaan 1, 8601 ZK Sneek, The Netherlands. ${ }^{2}$ Department of Critical Care, University Medical Center Groningen, University of Groningen, Hanzeplein 1, 9700RB Groningen, The Netherlands.

Published: 5 September 2011

\section{References}

1. Beutel G, Wiesner O, Eder M, Hafer C, Schneider AS, Kielstein JT, Kühn C, Heim A, Ganzenmüller T, Kreipe HH, Haverich A, Tecklenburg A, Ganser A, Welte T, Hoeper MM: Virus-associated hemophagocytic syndrome as a major contributor to death in patients with 2009 influenza A (H1N1) infection. Crit Care 2011, 15:R80.

2. van der Woude HJ, van der Werf TS, Verschuuren EA, Tamminga RY, Rosati S, Meertens JH, Zijlstra JG: An 18-year-old man with rapidly progressive multiorgan failure after a positive mononucleosis spot test result. Chest 2006, 130:291-295.

3. Okabe T, Shah G, Mendoza V, Hirani A, Baram M, Marik P: What intensivists need to know about hemophagocytic syndrome: an underrecognized cause of death in adult intensive care units. J Intensive Care Med 2011 Jan 21. [Epub ahead of print].

\section{doi:10.1186/cc10288}

Cite this article as: Linthorst $L$, et al:: Unexpected hemophagocytic syndrome in a post-cardiac surgery patient. Critical Care 2011, 15:440. 